\title{
THE
}

\section{Concentrations, Trends, and Air-Water Exchange of PCBs and Organochlorine Pesticides Derived from Passive Samplers in Lake Superior in 2011}

\author{
Zoe Ruge \\ University of Rhode Island \\ Derek Muir \\ Paul Helm \\ Rainer Lohmann \\ University of Rhode Island, rlohmann@uri.edu \\ Follow this and additional works at: https://digitalcommons.uri.edu/gsofacpubs
}

The University of Rhode Island Faculty have made this article openly available.

Please let us know how Open Access to this research benefits you.

This is a pre-publication author manuscript of the final, published article.

Terms of Use

This article is made available under the terms and conditions applicable towards Open Access

Policy Articles, as set forth in our Terms of Use.

\section{Citation/Publisher Attribution}

Ruge, Z., Muir, D., Helm, P., \& Lohmann, R. (2018). Concentrations, Trends, and Air-Water Exchange of PCBs and Organochlorine Pesticides Derived from Passive Samplers in Lake Superior in 2011. Environ.

Sci. Technol., 52(24), 14061-14069. doi: 10.1021/acs.est.8b04036

Available at: http://dx.doi.org/10.1021/acs.est.8b04036

This Article is brought to you for free and open access by the Graduate School of Oceanography at DigitalCommons@URI. It has been accepted for inclusion in Graduate School of Oceanography Faculty Publications by an authorized administrator of DigitalCommons@URI. For more information, please contact digitalcommons-group@uri.edu. 
Concentrations, trends, and air-water exchange of PCBs and organochlorine pesticides derived from passive samplers in Lake Superior in 2011

$5{ }^{1}$ Graduate School of Oceanography, University of Rhode Island, Narragansett, Rhode Island

$6 \quad$ 02882-1197, USA

$7 \quad{ }^{2}$ Environment and Climate Change Canada, Aquatic Contaminants Research Division, 867

8 Lakeshore Road, Burlington, Ontario L7S 1A1, Canada

$9{ }^{3}$ Ontario Ministry of the Environment, Conservation and Parks, Environmental Monitoring and

10 Reporting Branch, 125 Resources Road, Toronto, Ontario M9P 3V6, Canada

11 *email: rlohmann@uri.edu

12

\section{Graphical TOC}

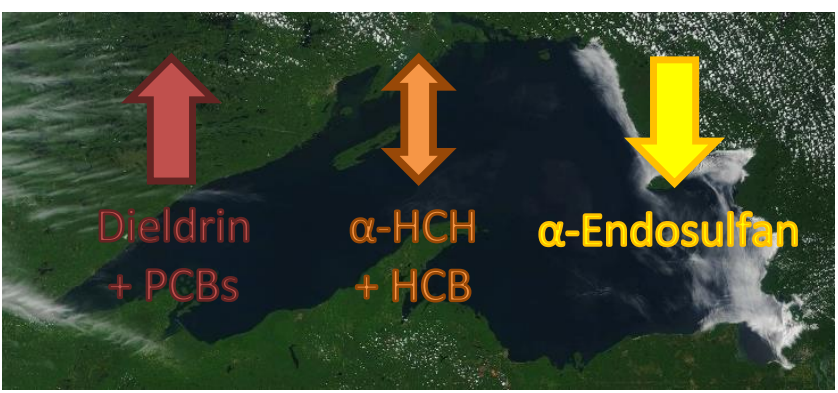

15

16 (TOC map from

17 http://coastwatch.glerl.noaa.gov/modis/modis.php?region=s\&page=4\&template=sub\&image=t1 .

$18 \quad$ 15206.1638.LakeSuperior.143.250m.jpg)

19

20 


\section{Abstract}

22 The largest fresh water body in North America, Lake Superior, has the potential to both accumulate

23 and serve as a secondary source of persistent bioaccumulative toxins, such as polychlorinated

24 biphenyls (PCBs) and organochlorine pesticides (OCPs). Polyethylene passive samplers (PEs)

25 were thus simultaneously deployed at 19 sites in surface water and near surface atmosphere across

26 Lake Superior to determine air and water concentrations and air-water gradients of 18 PCBs and

2724 OCPs. PCBs in the air and water were characterized by penta- and hexachlorobiphenyls with

28 distribution along the coast correlated with proximity to developed areas. Surface water and

29 atmospheric concentrations were dominated by $\alpha-\mathrm{HCH}$ (average $250 \mathrm{pg} \mathrm{L}^{-1}$ and $4.2 \mathrm{pg} \mathrm{m}^{-3}$,

30 respectively), followed by HCB (average $17 \mathrm{pg} \mathrm{L}^{-1}$ and $89 \mathrm{pg} \mathrm{m}^{-3}$, respectively). Decreases in open

31 lake concentrations of PCBs in water and air from spring to summer were consistent with on-going

32 volatilization from the surface layer as the main cause. Conversely, $\alpha$-endosulfan was consistently

33 deposited into the surface water of Lake Superior. Results implied that PCBs were depleted in the

34 surface mixed layer, implying a physical limit on evasive fluxes. This was corroborated with

35 measurements from a vertical profile, displaying greater PCB concentrations at depth. 
$\underline{\text { Introduction }}$

The Lake Superior watershed is the least industrialized and least populated of the Great

39 Lakes $^{1}$, and its air quality is considered to be representative of regional background atmospheric

40 concentrations. The largest agricultural regions in North America have historically been located to

41 the west and south/southeast of the Great Lakes. Organochlorine pesticides (OCPs) are transported

42 to Lake Superior by long-range atmospheric transport and deposited from the air into the surface

43 water by wet and dry deposition, as well as by diffusive chemical exchange. ${ }^{1,2,3}$ Passive transfer

44 of molecules across the air-water interface is driven by the concentration gradient of the analyte,

45 such that the additions of OCPs to surface water can reverse the gradient and result in

46 volatilization. ${ }^{3}$ Wind-speed was identified as the other key driver of air-water exchange fluxes. ${ }^{4}$

47 Lastly, volatilization is also strongly temperature-dependent, creating seasonal flux cycles with

48 greatest release to the atmosphere at the warmest time of year., ${ }^{5,6}$

49 Lake Superior's large surface area, long retention time, and colder water temperatures have

50 allowed accumulation of these persistent pollutants over the past several decades. ${ }^{7,8}$ OCP

51 concentrations in Great Lakes atmosphere and biota have been decreasing since regulatory controls

52 were put into effect. ${ }^{9,10,8}$ Reduced emissions from primary sources to the atmosphere have resulted

53 in steady state and even net volatilization of "legacy" OCPs from the surface water to the overlying

54 air. ${ }^{1}$ Continued losses of legacy pesticides from both the air and water may lead to the virtual

55 elimination of most OCPs from the Lake Superior environment by the mid- $21^{\text {st }}$ century. ${ }^{5}$ This trend

56 will be accelerated by the observed warming of Lake Superior water. ${ }^{11}$ Pesticides in current- or

57 recent-use, such as $\alpha$-endosulfan and its metabolites, may take longer to purge from Lake Superior.

58 Polychlorinated biphenyls (PCBs) share a similar timeline as OCPs. PCBs were used

59 extensively in industry and urban applications from the 1930 s through the 1970 s. ${ }^{12}$ They were one 
60 of the original persistent organic pollutants (POPs) added to the Stockholm Convention ${ }^{13}$ and are

61 known to bioaccumulate and cause adverse effects in fish, birds, and mammals in the Great Lakes

62 region. ${ }^{14}$ Prenatal exposure to PCBs in the Great Lakes region has resulted in lower IQ and 63 provided evidence that PCBs are neurobehavioral toxicants. ${ }^{15,16}$

64 There is very little information available on air and water trends of OCPs and PCBs in Lake

65 Superior. Most of the available atmospheric data stems from the IADN network, which operates

66 one master station in Lake Superior, at Eagle Harbor. Results from this invaluable long-term

67 monitoring network have shown the temporal trends of various organic pollutants in the

68 atmosphere. Yet, on the scale of the largest of the Great Lakes, there is little knowledge on spatial

69 trends across Lake Superior. ${ }^{17,18}$ A reversal of the air-water exchange of POPs leading to net

70 volatilization has been predicted ${ }^{2}$, but empirical evidence remains rare. ${ }^{18,19}$

71 Passive samplers provide an effective means of achieving good spatial coverage of Lake

72 Superior, as they can be deployed by various agencies as part of seasonal monitoring and servicing

73 of weather and/or navigational buoys, and can also be deployed by volunteers for simultaneous

74 deployments across multiple sites. Passive samplers, such as polyethylene (PE) samplers, rely on

75 diffusion to measure time-integrated gas- and freely dissolved-phase analytes ${ }^{20}$, excluding

76 confounding influences from particulates, precipitation, and colloids. ${ }^{21}$ The freely dissolved

77 fraction is important to the cycling of POPs because it is available for bio-uptake ${ }^{22}$ and free to

78 diffuse across the air-water boundary. ${ }^{20}$ PEs are an inexpensive alternative to active high-volume

79 air sampling and can expand spatial and temporal monitoring of Lake Superior. Additionally, PEs

80 can be deployed simultaneously in air and water to determine the magnitude of OCP exchanges

81 across the air-water interface at each deployment site. 
This study utilized PEs to measure gaseous and dissolved concentrations of various OCPs

83 and PCBs to (1) determine their overall concentrations and distribution patterns across Lake

84 Superior; (2) establish the direction of OCP and PCB gas exchange across the air-water interface

85 between mid- and late-summer 2011; and (3) derive time-trends of OCPs/PCBs in Lake Superior 86 relative to prior data.

\section{Materials and Methods}

Detailed materials and methods pertaining to the passive sampling and analytical methods

90 employed in this study were described in Ruge et al. (2015). ${ }^{23}$ Information specific to the PCB and

91 OCP analytes are specified below and in the Supporting Information.

93 Sampling Methodology

94 Low density polyethylene (2 mil) from commercial sheeting (Berry Plastics Corporation,

95 Evansville, IN) was cut into appx. 10x40 cm strips of appx. 2 g each. PEs were cleaned and spiked

96 with performance reference compounds (PRCs) as described previously. ${ }^{23}$ Air PEs were deployed

97 in inverted bowl stations at 11 coastal and 3 open-lake sites (see Table SI 1 and Figure SI 1).

98 Surface water PEs were deployed in tandem with the coastal air samplers, as well as at three open-

99 lake sites and two additional coastal sites. Samples were deployed for $\sim 2$ months each during 100 April-June, June-August, and August-October 2011. Duplicate air samples and triplicate water 101 samplers were deployed at two sites during each deployment. Field blanks were taken from 2-3

102 sites per deployment period. After retrieval, samplers were wrapped in foil, shipped to the lab and 103 stored at $4^{\circ} \mathrm{C}$ until analysis.

104

105 Analytical Methodology 
PEs were wiped clean with Kimwipes and extracted for 24 hours in ethyl acetate. Extracts

107 were spiked with $40 \mathrm{ng}$ of ${ }^{13} \mathrm{C}_{6} \mathrm{HCB}$ and ${ }^{13} \mathrm{C}_{12} \mathrm{p}$,p'-DDT surrogates (from Cambridge Isotopes,

108 Andover, MA, USA) and $50 \mathrm{ng}$ of labeled PCBs $\left({ }^{13} \mathrm{C}_{12}-\mathrm{CB} 8,{ }^{13} \mathrm{C}_{12}-\mathrm{CB} 28,{ }^{13} \mathrm{C}_{12}-\mathrm{CB} 52,{ }^{13} \mathrm{C}_{12-}\right.$

$109 \mathrm{CB} 118,{ }^{13} \mathrm{C}_{12}-\mathrm{CB} 138,{ }^{13} \mathrm{C}_{12}-\mathrm{CB} 180,{ }^{13} \mathrm{C}_{12}-\mathrm{CB} 209$ from Cambridge Isotopes, Andover, MA, USA)

110 to determine analyte recovery during sample processing. Target compounds were analyzed on

111 an Waters Quattro micro GS Micromass MS-MS (mass spectrometer) using 30m x 0.250mm

112 i.d. (film thickness $0.25 \mu \mathrm{m}$ ) DB-5MS column, as described elsewhere. ${ }^{24,25}$ OCP samples were held

113 at $100{ }^{\circ} \mathrm{C}$ for 1 minute, ramped up to $220^{\circ} \mathrm{C}$ at $5{ }^{\circ} \mathrm{C} / \mathrm{min}$ and held for 10 minutes, then ramped up

114 to $280{ }^{\circ} \mathrm{C}$ at $4{ }^{\circ} \mathrm{C} / \mathrm{min}$ and held for 5 minutes. PCB samples were held at $100{ }^{\circ} \mathrm{C}$ for 1 minute, 115 ramped up to $180{ }^{\circ} \mathrm{C}$ at $11^{\circ} \mathrm{C} / \mathrm{min}$, ramped up to $260^{\circ} \mathrm{C}$ at $3{ }^{\circ} \mathrm{C} / \mathrm{min}$, then ramped up to $300^{\circ} \mathrm{C}$ at $11620^{\circ} \mathrm{C} / \mathrm{min}$ and held for 6 minutes.

118 Quality Assurance/Quality Control

119 Method blanks were prepared with each batch of samples to monitor for laboratory 120 contamination (see Tables SI 6 and SI 18). Samples were blank-corrected by subtracting the 121 average of the method and field blank concentrations. Only sample amounts greater than three 122 times the standard deviation of the average blank values are reported. Standard checks were 123 analyzed every ten samples to monitor instrument performance.

124 Matrix spikes were prepared in each batch of approximately 20 samples. Spiked matrix 125 recoveries were typically ca. $80-120 \%$ for PCBs and $27-100 \%$ for OCPs (see Tables SI 7 and SI 126 19). 
At each site, 24 OCPs and 18 PCBs were determined (for details, see Tables SI 3 and SI

130 15). Truly dissolved concentrations of POPs in water, $\mathrm{C}_{\mathrm{W}}\left(\mathrm{ng} \mathrm{L}^{-1}\right)$, and gas-phase atmospheric

131 concentrations, $\mathrm{C}_{\mathrm{A}}\left(\mathrm{ng} \mathrm{m}^{-3}\right)$, were calculated according to Adams et al. (2007). ${ }^{26} \mathrm{~K}_{\text {PEW }}$ and $\mathrm{K}_{\text {PEA }}$

132 values were obtained from Lohmann $(2012)^{27}$, temperature-corrected, and used to determine air-

133 water exchange ratios as described in Ruge et al. (2015) ${ }^{23}$ (see SI pages 6-8).

$135 \quad$ Results and Discussion

136 Water Distributions

$137 \quad$ PCB Water Distributions

138 PCBs were detected at every site from June-August (Figure 1A). The highest and most 139 varied concentrations along the coast were at Sault Ste. Marie (40 pg L $\left.{ }^{-1}\right)$, followed by other urban 140 areas: Duluth $\left(7.4 \mathrm{pg} \mathrm{L}^{-1}\right)$, and Ashland $\left(6.9 \mathrm{pg} \mathrm{L}^{-1}\right)$. Coastal rural sites exhibited the lowest

141 dissolved concentrations $\left(<1 \mathrm{pg} \mathrm{L}^{-1}\right)$, while open lake sites were similar to developed coastal areas 142 (2.6-7.0 pg L ${ }^{-1}$ ) (Table 1). Hexa- and pentachlorinated congeners dominated in the water at 143 approximately half of the sampling sites while tri- and tetrachlorinated congeners dominated 144 dissolved concentrations at Duluth, Ashland, and the open lake sites.

145 In August-October distributions and relative congener contributions were nearly the same 146 as in June-August, with the exceptions of Duluth and the open lake sites (Table 1). At these 147 locations, dissolved concentrations decreased dramatically due to losses of tri- and 148 tetrachlorobiphenyl (Figure 1B).

$149 \quad$ Venier et al. (2014) $)^{17}$ used XAD-2 resin adsorption to sample three nearshore sites $(<20 \mathrm{~m}$ 150 depth) and three offshore stations (>50 m depth) in spring 2011, reporting an average total PCB 151 (sum of 84 congeners) concentration of $120 \pm 18 \mathrm{pg} \mathrm{L}^{-1}$. The comparison is complicated by the fact 152 that grab samples are compared to an integrated sampler over weeks, different laboratories 
153 performed the analysis, and that active sampling co-extracts analytes bound to colloids. Not 154 surprisingly, better agreement was found for compounds with lower affinity for colloids (HCHs, 155 HCB, see below).

\section{OCP Water Distributions}

158 Overview

Eight OCPs were measured above the detection limit at all sites from June-October: $\alpha$ -

$160 \mathrm{HCH}, \mathrm{HCB}$, heptachlor epoxide, trans- and cis-chlordane, trans-nonachlor, p,p'-DDE, and 161 combined p,p'-DDD+o,p'-DDT (Table 2). Marquette and Sturgeon Bay were not measured from 162 August-October, so are excluded from spatial averages. $\alpha$-Endosulfan was not consistently 163 detected in the water. Dissolved OCP concentrations in Lake Superior surface water were 164 dominated by $\alpha-\mathrm{HCH}$ (average $250 \mathrm{pg} \mathrm{L}^{-1}$ ), followed by HCB (average $17 \mathrm{pg} \mathrm{L}^{-1}$ ) (Table 2). 165 Heptachlor epoxide was present at fairly uniform concentrations across the lake (1.1-5.5 $\mathrm{pg} \mathrm{L}^{-1}$ ).

166 Dieldrin was also present at most coastal sites (average $24 \mathrm{pg} \mathrm{L}^{-1}$ ). Deposition from the atmosphere 167 by precipitation and gas exchange has historically been the input of OCPs to Lake Superior ${ }^{28}$ rather 168 than from inflow of contaminants in tributaries. For many of these compounds, the dissolved 169 concentrations decreased at most sites from June-August to August-October, with the exceptions 170 of $\alpha-\mathrm{HCH}$, heptachlor epoxide, and dieldrin. Ontonagon exhibited increased concentrations of 171 most of these compounds over the same time period (see Table SI 20).

\section{Hexachlorocyclohexane $(\mathrm{HCH})$}

174 Technical $\mathrm{HCH}$ is a mixture of five $\mathrm{HCH}$ isomers used as a broad-spectrum insecticide in 175 the United States and Canada from the 1940s to 1970s; while lindane $(\gamma-\mathrm{HCH})$ was used until the 
176 mid 2000s. ${ }^{12} \alpha-\mathrm{HCH}$ was the dominant dissolved OCP (ca. 40-90\% of total OCPs measured)

177 (Figure 2A), >10 times HCB concentrations, opposite to atmospheric ratios (see below). Excluding

178 Ontonagon, where $\alpha-\mathrm{HCH}$ was only $12 \mathrm{pg} \mathrm{L}^{-1}$, the average concentration in surface lake water was

$179270 \mathrm{pg} \mathrm{L}^{-1}$ (range $120 \mathrm{pg} \mathrm{L}^{-1}$ at Eagle Harbor to $450 \mathrm{pg} \mathrm{L}^{-1}$ in eastern open lake water).

180 Concentrations of $\alpha-\mathrm{HCH}$ decreased at open lake sites up to three times between June-August and

181 August-October, when temperature changes in both the atmosphere and surface water were

182 greatest. Venier et al. (2014) also found $\alpha-\mathrm{HCH}$ to be the dominant pesticide in Lake Superior

183 (average $300 \pm 80 \mathrm{pg} \mathrm{L}^{-1}$ ). ${ }^{17}$

184

\section{Hexachlorobenzene $(\mathrm{HCB})$}

186 HCB is a former pesticide, impurity in other OCPs, and a byproduct of chlorine-based 187 bleaching. ${ }^{5,29} \mathrm{HCB}$ was also present at all monitored sites, and exhibited similar distribution 188 patterns as $\alpha-\mathrm{HCH}$. Coastal concentrations were fairly uniform, mostly ranging from 5.4 to $18 \mathrm{pg}$ $189 \mathrm{~L}^{-1}$. Again, the open lake sites exhibited concentrations (average $23 \mathrm{pg} \mathrm{L}^{-1}$ ) greater than the coastal 190 sites. $\mathrm{HCB}$ concentrations at Ashland were unusually elevated at $37 \mathrm{pg} \mathrm{L}^{-1}$. In addition to its 191 application to agricultural seeds as an antifungal agent, $\mathrm{HCB}$ was also emitted in the waste streams 192 of wood-preserving plants and the incineration of municipal waste. ${ }^{30}$ Lumber treatment and other 193 heavy industry in Ashland could be the source of this HCB signal in the nearby water. Venier et 194 al. (2014) reported an average concentration of $12 \pm 2.6 \mathrm{pg} \mathrm{L}^{-1} \cdot{ }^{17}$

195

Heptachlor Epoxide

197 Heptachlor epoxide is the product of heptachlor degradation. Like heptachlor, it is 198 persistent, bioaccumulative, and toxic. ${ }^{31}$ Heptachlor epoxide represented ca. 1-2\% total OCP 
199 concentrations at most coastal sites. Heptachlor epoxide concentrations were fairly uniform across

200 the lake, ranging from 1.1 to $5.5 \mathrm{pg} \mathrm{L}^{-1}$. Its parent compound, heptachlor, was only measured

201 sporadically and at very low concentrations, implying no new input to the Lake. Venier et al.

202 (2014) reported an average concentration of $39 \pm 17 \mathrm{pg} \mathrm{L}^{-1} .^{17}$

204 Chlordane

205 Technical chlordane (trans-chlordane (TC), cis-chlordane (CC), and trans-nonachlor) was

206 used as an insecticide, herbicide, and termiticide between 1947 and 1988 at which time it was

207 deregistered for all uses in the United States, and 1990 when it was banned for all uses in

208 Canada. $^{3,29,30}$ The sum of trans- and cis-chlordane was elevated at urban and industrial sites

209 (average ca. $1.2 \mathrm{pg} \mathrm{L}^{-1}$ ) compared to rural sites (Eagle Harbor $0.39 \mathrm{pg} \mathrm{L}^{-1}$ ).

210 Urban sources near the Great Lakes, namely Chicago and Toronto, have continued

211 emissions of racemic chlordane $(\mathrm{TC} / \mathrm{CC}=1.17) .{ }^{10}$ However, rural Great Lakes sites have low

212 TC/CC ratios (annual average 0.72$)^{10}$, suggesting atmospheric chlordane concentrations in the

213 region are aged and volatilized from microbially-processed soils. ${ }^{29}$ In our study, TC/CC ratios

214 averaged 0.84, but were as low as 0.54 at Eagle Harbor. This was in contrast to atmospheric

215 chlordane signatures in this study, which were racemic (see below), implying tributaries and

216 sediments as likely sources of aged chlordanes to the water column. Venier et al. (2014) reported

217 an average cis-chlordane concentration of $32 \pm 30 \mathrm{pg} \mathrm{L}^{-1}$, and an average trans-chlordane

218 concentration of $19 \pm 18 \mathrm{pg} \mathrm{L}^{-1}$, resulting in a lake-wide average TC/CC of $0.59 .{ }^{17}$

219

220 Dichlorodiphenyltrichloroethane (DDT) 
Technical DDT (65-80\% p,p'-DDT, 15-21\% o,p'-DDT, $<4 \%$ p,p'-DDD) was used

222 extensively in the 1940s and 1950s in urban aerial sprays to control mosquitoes ${ }^{9}$ and widely used

223 on a variety of agricultural crops in the 1960s. ${ }^{29}$ DDTs are less volatile than most OCPs;

224 concentrations tend to be greater near urban sources and contaminated soils ${ }^{29,9}$; though there is

225 evidence of long-range transport from its recent use further south. ${ }^{32}$ p,p'-DDT was not measured

226 above the detection limit at every site; where detected, it was $<0.7 \mathrm{pg} \mathrm{L}^{-1}$. The presence of DDT

227 metabolites and overall low concentrations indicate no new inputs of technical DDT in the Lake

228 Superior region (see Table SI 20). These results agree with previous sediment measurements where

229 surficial sediment concentrations of DDE $\left(0.43 \mathrm{ng} \mathrm{g}^{-1}\right)$ were also greater than those of DDT (0.11

$\left.230 \mathrm{ng} \mathrm{g}{ }^{-1}\right) .{ }^{8}$ Venier et al. (2014) reported average concentrations of $28 \pm 24 \mathrm{pg} \mathrm{L}^{-1}, 4.0 \pm 2.0 \mathrm{pg} \mathrm{L}^{-1}$,

$23127 \pm 22 \mathrm{pg} \mathrm{L}^{-1}$ for $\mathrm{p}, \mathrm{p}^{\prime}-\mathrm{DDT}$, o,p'-DDT, and p,p'-DDD, respectively. ${ }^{17}$ Lower concentrations

232 derived from passive sampling could indicate the importance of colloidal or particle-associated

233 DDT or chlordane captured by the active sampling.

Dieldrin

236 Dieldrin was used extensively from 1950 to 1974 as an insecticide on cotton, corn, citrus

237 fruits, as well as for termite control. ${ }^{13,29}$ It was banned for most uses in the United States in $1987 .{ }^{34}$

238 In addition to direct emissions, dieldrin is also metabolized from aldrin, another insecticide also

239 listed on the Stockholm Convention of POPs ${ }^{13}$, and both are highly toxic to humans. ${ }^{35}$ Dieldrin

240 was regularly present in the water at many sites, in stark contrast to the air, where it was not

241 consistently detected. Where present, dieldrin represented 10-20\% of total dissolved OCPs

242 measured in Lake Superior water. Excluding Ontonagon, Duluth, and the open lake sites where

243 the analyte was not present above the detection limit, average dieldrin concentration was $45 \mathrm{pg} \mathrm{L}^{-}$ 
$244{ }^{1}$. Dieldrin was twice as high at Pointe Aux Pins, the only site that exhibited consistent dieldrin

245 concentrations in the air (average $5.0 \mathrm{pg} \mathrm{m}^{-3}$ ). Venier et al. (2014) reported an average

246 concentration of $57 \pm 15 \mathrm{pg} \mathrm{L}^{-1} \cdot{ }^{17}$

\section{Endosulfan}

$\alpha$-Endosulfan is a broad spectrum insecticide used on fruits, vegetables, cotton, tobacco, 250 and trees, as well in the preservation of wood. ${ }^{7,29}$ Use began in the 1950 s and continued until

251 recently in the US and Canada. ${ }^{35} \alpha$-Endosulfan was not consistently detected in Lake Superior 252 water, only averaging $0.63 \mathrm{pg} \mathrm{L}^{-1}$. Venier et al. (2014) reported an average concentration of $32 \pm 21$

$253 \mathrm{pg} \mathrm{L}{ }^{-1} \cdot{ }^{17}$ Endosulfan sulfate, an endosulfan metabolite, was only detected at a few sites from June-

254 October (averaging 44-360 $\mathrm{pg} \mathrm{L}^{-1}$ ). The presence of this metabolite may possibly indicate a 255 tendency for endosulfan to degrade in Lake Superior water, however measurements were very 256 inconsistent and do not illustrate any definitive trends.

\section{Air Distributions}

\section{$259 \quad$ PCB Air Distributions}

260 PCBs were detected in the atmosphere at nearly every site during the sampling season, 261 however distributions were not spatially and temporally uniform. Sault Ste. Marie and Marquette 262 had the highest $\Sigma_{18} \mathrm{PCB}$ concentrations from June-August (49 and $59 \mathrm{pg} \mathrm{m}^{-3}$, respectively), >20x 263 higher than the other sites (Table 1). These two sites also had the greatest number of different PCB 264 congeners present above detection (Figure 1C), suggesting that Sault Ste. Marie and Marquette are 265 current sources of PCBs, probably due to historical use of these compounds at both locations. In 266 general, PCB concentrations were higher and more diverse near populated or industrialized areas, 
267 as expected for anthropogenic products with no known natural emissions. ${ }^{3,36,37}$ Despite 268 associations with larger populations, PCB concentrations were relatively low at the Duluth and 269 Thunder Bay/Welcome Isle stations over the same time period ( 3.4 and $4.3 \mathrm{pg} \mathrm{m}^{-3}$, respectively). 270 As mentioned elsewhere ${ }^{23}$, the Duluth site was located northeast of the downtown while the

271 Welcome Isle site was $7 \mathrm{~km}$ southeast of the nearest ship and rail facilities in Thunder Bay. Thus

272 neither site may have received direct emissions from the city. Likewise, historical consumption of 273 PCBs was lower in Canada than in the United States (3\% of global use versus 46\%), possibly 274 contributing to lower observed concentrations at Thunder Bay. ${ }^{3,38}$ Significant quantities of PCBs 275 are still in use as dielectric fluids in transformers and capacitors in the industrialized regions to the 276 south of Lake Superior ${ }^{14}$, likely contributing to atmospheric PCB levels along the southern shore. 277 Current atmospheric PCB levels indicate a decrease in gaseous PCBs in Lake Superior air over the 278 past decade, even accounting for different number of congeners being included. Previous IADN 279 studies reported $\mathrm{SPCB}$ at Eagle Harbor ca. 63-95 $\mathrm{pg} \mathrm{m}^{-3}$ from 1990-2003.6,36,38

280 Hexachlorinated congeners dominated in the atmosphere across the lake from June-August 281 (see Table SI 12), representing 40-100\% of gaseous concentrations. $\Sigma_{18} \mathrm{PCB}$ concentrations at 282 Sault Ste. Marie and Marquette also had significant contributions from tetra- (33\% and 54\%, 283 respectively) and pentachlorobiphenyls (30\% and 39\%, respectively).

284 Although general distribution patterns of $\Sigma_{18} \mathrm{PCB}$ were similar, atmospheric concentrations 285 decreased at a number of sites from the June-August deployment to the August-October 286 deployment (Figure 1D), in particular at the open Lake sites. 
Nine analytes were consistently found in the gas-phase across the lake: $\alpha-\mathrm{HCH}, \mathrm{HCB}, \alpha-$

291 endosulfan, heptachlor epoxide, trans-chlordane, cis-chlordane, trans-nonachlor, p,p'-DDE, and

292 combined p,p'-DDD+o,p'-DDT (Table 2). Concentrations were averaged for each site over the

293 second and third deployments (June-October 2011). Gaseous OCP concentrations in the

294 atmosphere were dominated by HCB at all sites across Lake Superior (Figure 2B), within a narrow

295 range $\left(42-130 \mathrm{pg} \mathrm{m}^{-3}\right) \cdot \alpha-\mathrm{HCH}$ was also routinely detected, at an average of $4.3 \mathrm{pg} \mathrm{m}^{-3}$. Of the

296 other 24 OCP analytes measured, only $\alpha$-endosulfan was present above $1 \mathrm{pg} \mathrm{m}^{-3}$ (average $1.7 \mathrm{pg}$

$297 \mathrm{~m}^{-3}$ ). The greatest concentration of $\alpha-\mathrm{HCH}$ was measured at Thunder Bay/Welcome Isle (9.6 pg

$\left.298 \mathrm{~m}^{-3}\right)$, followed closely by ODAS45004 $\left(9.1 \mathrm{pg} \mathrm{m}^{-3}\right)$ and the two other open lake sites. The greatest

299 concentrations of $\alpha$-endosulfan and chlordanes were detected in populated areas. In general, lowest

300 concentrations of heptachlor epoxide, $\alpha$-endosulfan, chlordanes, and DDTs were found in the open

301 lake atmosphere at stations ODAS45001 and ODAS45006. Conversely, the eastern open lake site,

302 ODAS45004, exhibited slightly elevated concentrations, similar to Thunder Bay and other

303 populated areas (see Table SI 21).

305 Hexachlorocyclohexane $(\mathrm{HCH})$

306 Relatively uniform distribution across Canada and the United States is expected for a

307 persistent compound with no current use. ${ }^{39}$ Our results are consistent with these patterns, showing

308 fairly uniform distributions of $\alpha-\mathrm{HCH}$ across Lake Superior, where it is present at almost every

309 site (range 1.0 to $9.6 \mathrm{pg} \mathrm{m}^{-3}$; below detection at Michipicoten Bay). Previous studies of OCPs in

310 the atmosphere over Lake Superior ${ }^{40}$ reported an $\alpha-\mathrm{HCH}$ range of 6-170 $\mathrm{pg} \mathrm{m}^{-3}$ with decreasing

311 trends over the past 20 years. ${ }^{5,12,39}$ Since production was discontinued, atmospheric concentrations

312 of $\alpha-\mathrm{HCH}$ are no longer determined by primary sources, but are now primarily a result of 
313 evaporation from terrestrial and aquatic surfaces. ${ }^{39}$ Our data suggests that $\alpha-\mathrm{HCH}$ is revolatilizing

314 from Lake Superior (see OCP air-water exchange below), causing atmospheric concentrations over

315 open lake waters to be slightly elevated relative to coastal lake regions.

316 The remainder of technical $\mathrm{HCH}$ historically produced was composed of $1-13 \% \beta-\mathrm{HCH}$

317 and $10-15 \% \gamma-\mathrm{HCH}$, or lindane. These two isomers were not detected regularly across Lake

318 Superior in this study (see Table SI 21).

Hexachlorobenzene $(\mathrm{HCB})$

321 HCB dominated in Lake Superior air, representing $>80 \%$ of the OCPs measured at every

322 site. Like $\alpha-\mathrm{HCH}$, it is thought that the current source of HCB to the atmosphere is volatilization

323 from contaminated soils and possibly from large bodies of water as atmospheric concentrations

324 decrease and permit an equilibrium shift across the air-water interface. ${ }^{10,29,24} \mathrm{HCB}$ was relatively

325 elevated everywhere across Lake Superior, measured at all sites with a range of $42 \mathrm{pg} \mathrm{m}^{-3}$ at

326 Ontonagon to $130 \mathrm{pg} \mathrm{m}^{-3}$ at Foster Island. Average Eagle Harbor gaseous concentration was $65 \mathrm{pg}$

$327 \mathrm{~m}^{-3}$, similar to the value reported from $2000-2001\left(80 \mathrm{pg} \mathrm{m}^{-3}\right) \cdot{ }^{29}$

\section{Endosulfan}

330 Previous studies conducted from 2000-2001 reported $\alpha$-endosulfan to be the dominant OCP

331 in the North American atmosphere (range 3.1-690 $\mathrm{pg} \mathrm{m}^{-3}$ ), with Lake Superior concentrations

332 among the lowest across the continent $\left(27 \mathrm{pg} \mathrm{m}^{-3}\right) \cdot{ }^{29}$ Results from our study indicated similar

333 concentrations, ranging from 0.33 to $2.7 \mathrm{pg} \mathrm{m}^{-3}$. Open lake sites at Stations ODAS45001 and

334 ODAS45006 had the lowest concentrations ( 0.44 and $0.33 \mathrm{pg} \mathrm{m}^{-3}$, respectively), possibly as a 335 result of their distance from terrestrial sources where this compound is still being emitted. 
336 However, the eastern open lake site, ODAS45004, displayed a concentration similar to coastal

337 sites $\left(2.5 \mathrm{pg} \mathrm{m}^{-3}\right)$. $\beta$-endosulfan was not significantly present at any of the Lake Superior sites

338 included in this study (see Table SI 21). Endosulfan sulfate, a degradation product of endosulfan,

339 was only detected in the atmosphere at a few sites and at very low concentrations. Concentrations

340 may be lower than 2000-2001 values due to the recent (2012-2016) discontinuation of use in the

341 US and Canada between sampling periods, or due to sampling differences between polyethylene

342 and $\mathrm{XAD}$ passive sampling.

\section{Heptachlor epoxide}

345 Heptachlor epoxide was detected in the atmosphere at all sites across Lake Superior at an 346 average of $0.67 \mathrm{pg} \mathrm{m}^{-3}$ (range $0.30-1.1 \mathrm{pg} \mathrm{m}^{-3}$ ) from June-October. Concentrations were low and 347 fairly uniform across the lake, in-line with its volatilization from soils. Concentrations greater than $3481 \mathrm{pg} \mathrm{m}^{-3}$ were measured at Thunder Bay/Welcome Isle and Sault Ste. Marie, two populated areas 349 where heptachlor may have been used by the shipping industry. The eastern open lake site also 350 displayed concentrations of $1.1 \mathrm{pg} \mathrm{m}^{-3}$. Secondary sources are also suggested by inconsistent 351 detection of heptachlor, which is more volatile than heptachlor epoxide and is expected to dissipate 352 more quickly by evaporation. ${ }^{31}$ Heptachlor, a parent compound of its epoxide, impurity in 353 chlordane, was present at fewer than half of the sites, mainly elevated near populated and industrial 354 areas, highest at Thunder Bay/Welcome Isle $\left(1.2 \mathrm{pg} \mathrm{m}^{-3}\right)$.

\section{Chlordane}

Total chlordane (sum of trans-chlordane and cis-chlordane) averages from June to October

358 ranged from 0.19 to $1.6 \mathrm{pg} \mathrm{m}^{-3}$, generally greater near urban areas (average $1.0 \mathrm{pg} \mathrm{m}^{-3}$ ) and lower 
at rural (average $0.58 \mathrm{pg} \mathrm{m}^{-3}$ ). Previous gas-phase measurements at Eagle Harbor from 1996-1998 were $8.6 \pm 1.3 \mathrm{pg} \mathrm{m}^{-3}$, ten times higher than values measured in this study. ${ }^{6}$

\section{Dichlorodiphenyltrichloroethane (DDT)}

Technical DDT compounds measured in this study were present across Lake Superior at

364 very low concentrations $\left(<0.77 \mathrm{pg} \mathrm{m}^{-3}\right)$. p,p'-DDT was often below detection and p,p'-DDD+o,p'-

365 DDT was detected at low concentrations at every site (0.018-0.44 $\left.\mathrm{pg} \mathrm{m}^{-3}\right)$. Average p,p'-DDE 366 concentrations ranged from 0.075 to $1.4 \mathrm{pg} \mathrm{m}^{-3}$ during the sampling period, highest at Marquette $367\left(1.4 \mathrm{pg} \mathrm{m}^{-3}\right)$ and Sault Saint Marie $\left(1.1 \mathrm{pg} \mathrm{m}^{-3}\right)$.

Dieldrin

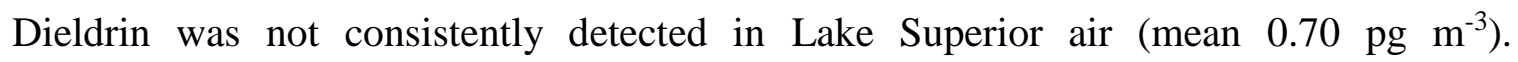

371 Atmospheric concentration at Eagle Harbor was $8.8 \pm 1.4 \mathrm{pg} \mathrm{m}^{-3}$ in $1996-1998^{6}$ and $7.5 \mathrm{pg} \mathrm{m}^{-3}$ in

372 2000-2001 29 , however, it was below detection in atmospheric samples for this study. Dieldrin was

373 only present at one site, Pointe Aux Pins, both during the June-August sampling period and the

374 August-October sampling period (average $5.0 \mathrm{pg} \mathrm{m}^{-3}$ ). Aldrin and endrin were generally below 375 detection in the atmosphere over Lake Superior.

\section{PCB Air-Water Exchange}

379 locations with the highest dissolved-phase concentrations: Sault Ste. Marie, Pointe Aux Pins, 380 Duluth, Ashland, and the eastern open lake. Sault Ste. Marie, Pointe Aux Pins, and Ashland 381 exhibited net volatilization of hexachlorobiphenyls, while the eastern open lake site exhibited net 
382 volatilization of tetrachlorobiphenyls, and all open lake site air-water ratios indicated volatilization

383 of trichlorobiphenyls. Marquette exhibited net deposition of tetra- and pentachlorobiphenyls. Most

384 other sites had fluxes either below detection or not significantly different from equilibrium.

385 From August-October, hexachlorobiphenyls were significantly volatilizing at more sites

386 across Lake Superior than June-August, the predominant PCBs volatilizing at Sault Ste. Marie,

387 Point Aux Pins, Ashland, Ontonagon, Sturgeon Bay, and the open lake sites. The open lake sites 388 also exhibited volatilization of pentachlorobiphenyls.

\section{PCB trends in water due to evaporation}

The observed evaporative flux of PCB 52 was sufficient to effectively remove it from a 392 well-mixed surface mixed layer (ML) of ca. $20 \mathrm{~m}$. This was in-line with our observation that 393 dissolved concentrations during the August-October deployment were below the detection limit.

394 In turn, this would suggest that the open Lake Superior could repeatedly lose the amount of PCBs 395 contained in the ML. In other words, the evaporative loss is limited physically by the proportion 396 of POPs residing in the surface ML depth $(\sim 20 \mathrm{~m})$ to the average lake depth $(150 \mathrm{~m}) .{ }^{41}$ This should 397 lead to a concentration gradient across the thermocline, with greater concentrations in deeper, non398 ventilated water layers. To test this, passive samplers were deployed at $48.860 \mathrm{~N}, 91.930 \mathrm{~W}$ from 399 May-November 2015 at $1 \mathrm{~m}$ and $40 \mathrm{~m}$ depth. Indeed, PCB concentrations in deeper water were 400 either similar or greater than at surface, in-line with our expectations (see Figure 3, Table SI 9). In 401 the case of higher MW congener, such as PCB 209, their relative depletion in the surface is 402 probably the result of settling with particles (biological pump). ${ }^{42}$ 
PCB concentrations in the Lake Superior water column have been declining for the past

406 few decades ${ }^{12,28}$, removed primarily by volatilization rather than sedimentation. ${ }^{43}$ Overall half-

407 lives for PCBs in both the air and water were estimated to be 5-9 years. ${ }^{1}$

408 We also compared our derived average dissolved congener concentrations to those 409 measured in Lake Superior in 1993 and 1997 by Environment Canada. For the few congeners that

410 were regularly detected in all three years (see Table SI 10), there was a general steep decrease in 411 concentration observed, with $\mathrm{t}_{1 / 2}$ on the order of 5-15 years (we note that these half-lives are not

412 statistically significant with $\mathrm{n}=3$, but indicate a strong trend). This is very similar in magnitude to 413 the latest time-trends reported by IADN for atmospheric PCBs. ${ }^{44}$

\section{OCP Air-Water Exchange}

416 From June-August, many OCP analytes were either below detection or exhibited air-water 417 ratios not significantly different from equilibrium (ratio of the PE-concentrations at equilibrium $418>3.9$ or $<0.14$ ), as expected for compounds with no current emission sources. Two notable 419 exceptions were the observed deposition of $\alpha$-endosulfan at most sites, and the volatilization of $\alpha$ $420 \mathrm{HCH}$ at Duluth, Michipicoten Bay, and Sturgeon Bay.

421 From August-October, $\alpha$-endosulfan continued to deposit into the lake. Additionally, 422 where present, dieldrin and oxychlordane volatilized from most sites. Spatially, Ashland and 423 Ontonagon displayed net deposition of many analytes present, notably $\mathrm{HCH}$ congeners. The 424 central and western open lake sites generally exhibited net volatilization of the analytes present, in 425 contrast to the eastern open lake site, where most detected analytes were being deposited into Lake 426 Superior. HCB exchange ratios were indicative of equilibration at most sites, and $\alpha-\mathrm{HCH}$ was only 427 significantly volatilizing at Point Aux Pins and Michipicoten. 
Our results imply trends of $\alpha-\mathrm{HCH}$ and $\mathrm{HCB}$ air-water exchange consistent with

429 diminishing sources to Lake Superior. In 2002-2003, HCB was reported undergoing net

430 deposition, while $\alpha-\mathrm{HCH}$ was approximately in equilibrium ${ }^{40}$ with subsequent observations of 431 volatilization from Lake Superior surface water. ${ }^{10,39}$ Similarly, Lake Superior seems to be serving 432 as an important secondary source of dieldrin to the atmosphere at some sites.

\section{Implications}

PCB concentrations measured in the air and water across Lake Superior exhibited a clear

436 association with urban and industrial areas, consistent with past findings in the Great Lakes

437 region. ${ }^{45}$ Decreases in open lake concentrations of PCBs in water and air from spring to summer

438 were consistent with on-going volatilization from the surface layer as the main cause. This was

439 corroborated with measurements from a vertical profile, displaying greater PCB concentrations at

440 depth. Comparison to previously reported dissolved PCB concentrations imply an on-going

441 recovery of Lake Superior from PCBs, with half-lives ranging from 5-15 years.

OCP concentrations were dominated by gaseous HCB in the air and dissolved $\alpha-\mathrm{HCH}$ in

443 the water. Their detection at nearly every site and relatively even distributions are consistent with

444 trends of persistent pesticides with a history of extensive use and well-established regulation. Air-

445 water exchange gradients for $\mathrm{HCB}$ and $\alpha-\mathrm{HCH}$ tended to be either near equilibrium or volatilizing

446 from the surface of Lake Superior to the atmosphere. Most other legacy compounds were present

447 at very low concentrations and appear to be cycling between the air and water, indicating near-

448 steady state fluxes and overall trends toward virtual elimination from the Lake Superior

449 environment. OCPs with recent emissions, such as $\alpha$-endosulfan, were still undergoing 
450 atmospheric transportation to the lake, resulting in strong net deposition across the entire lake 451 surface.

452 Continued monitoring is required to determine the long-term effects of regulation and fate 453 of these compounds in the Lake Superior region. Polyethylene passive samplers make it possible 454 to easily and affordably monitor continuing POP trends at a high resolution, distinguishing 455 between background concentrations likely transported over long distances and local influences 456 from populated areas. PEs could be deployed year-round over the next several years to fully 457 establish seasonal and annual cycles in addition to long-term trends. In addition, passive samplers 458 can be biomimetic of lower trophic levels, as the uptake of POPs by PE or lipids is similar in 459 nature. Passive samplers can thus also serve as useful proxies for understanding and predicting the 460 bioaccumulation of persistent organic chemicals by lower trophic levels. ${ }^{46}$

\section{Supporting Information Available}

463 Additional information on sampling locations, physicochemical constants, sampling rates, 464 QA/QC, analysis, calculations and concentrations of PCBs and OCPs and their air-water exchange 465 available free of charge via the Internet at http://pubs.acs.org/.

\section{Acknowledgements}

468 We acknowledge funding from the US EPA Great Lakes Restoration Initiative GLAS \#00E00597469 0, Project Officer Todd Nettesheim, and from the Great Lakes Air Deposition Program, \#GLAD 470 2010-5. RL acknowledges a Fellowship at the Hanse-Wissenschaftskolleg Institute for Advanced 471 Study, Delmenhorst, Germany. We would like to thank Peter August (URI) for GIS assistance, 472 David Adelman (URI) for organizing deployments, Camilla Teixeira and the field staff of the 473 Emergencies, Operational Analytical Laboratories, and Research Support group (Environment 
475 of the Environment, Conservation and Parks) for Canadian nearshore deployments, Jay Austin

476 (University of Minnesota) for vertical deployments, Allison Pugh (Environmental Canada

477 Burlington, Water Quality Monitoring and Surveillance Division) for water temperature data, Dr.

478 Mohammed Khairy (URI) for assistance with data analysis and interpretation, and all of the 479 volunteers who deployed PEs in the region.

\section{$\underline{\text { References }}$}

(1) Hillery, B.R.; Simcik, M.F.; Basu, I.; Hoff, R.M.; Strachan, W.M.J.; Burniston, D.; Chan, C.H.; Brice, K.A.; Sweet, C.W.; Hites, R.A. Atmospheric deposition of toxic pollutants to the Great Lakes as measured by the Integrated Atmospheric Deposition Network. Environ. Sci. Technol. 1998, 32, 2216-2221.

(2) Swackhamer, D.L.; Schottler, S.; Pearson, R.F. Air-water exchange and mass balance of toxaphene in the Great Lakes. Organohalogen Compd. 1999, 33, 3864-3872.

(3) Hafner, W.D. and Hites, R.A. Potential sources of pesticides, PCBs, and PAHs to the atmosphere of the Great Lakes. Environ. Sci. Technol. 2003, 37, 3764-3773.

(4) Achman, D.R.; Hornbuckle, K.C.; Eisenreich, S.J. Volatilization of Polychlorinated Biphenyls from Green Bay, Lake Michigan. Environ. Sci. Technol. 1993, 27, 75-87.

(5) Cortes, D.R.; Basu, I.; Sweet, C.W.; Brice, K.A.; Hoff, R.M.; Hites, R.A. Temporal trends in gasphase concentrations of chlorinated pesticides measured at the shores of the Great Lakes. Environ. Sci. Technol. 1998, 32, 1920-1927.

(6) Buehler, S.S.; Basu, I.; Hites, R.A. A comparison of PAH, PC, and pesticide concentrations in air at two rural sites on Lake Superior. Environ. Sci. Technol. 2001, 35, 2417-2422.

(7) Buehler, S.S.; Basu, I.; Hites, R.A. Causes of variability in pesticide and PCB concentrations in air near the Great Lakes. Environ. Sci. Technol. 2004, 38, 414-422.

(8) Gewurtz, S.B.; Shen, L.; Helm, P.A.; Waltho, J.; Reiner, E.J.; Painter, S.; Brindle, I.D.; Marvin, C.H. Spatial distribution of legacy contaminants in sediments of Lakes Huron and Superior. J. Great Lakes Res. 2008, 34, 153-168.

(9) Sun, P.; Backus, S.; Blanchard, P.; Hites, R.A. Temporal and spatial trends of organochlorine pesticides in Great Lakes precipitation. Environ. Sci. Technol. 2006, 40, 2135-211.

(10)Gouin, T.; Jantunen, L.; Harner, T.; Blanchard, P.; Bidleman, T. Spatial and temporal trends of chiral organochlorine signatures in Great Lakes air using passive air samplers. Environ. Sci. Technol. 2007, 41, 3877-3883.

(11)Austin, J. and Colman, S. A century of temperature variability in Lake Superior. Limnol. Oceanogr. 2008, 53, 2724-2730.

(12)Buehler, S.S. and Hites R.A. The Great Lakes' Integrated Atmospheric Deposition Network. Environ. Sci. Technol. 2002, 36, 354A-359A.

(13)United Nations Environmental Programme Stockholm Convention on Persistent Organic Pollutants Website; http://chm.pops.int. 
(14)Suchash, S.; Honrath, R.E. Kahl, J.D.W. Back-trajectory analysis of atmospheric polychlorinated biphenyl concentrations over Lake Superior. Environ. Sci. Technol. 1999, 33, 1509-1515.

(15)Stewart, P.W.; Reihman, J.; Lonky E.I.; Darvill, T.J.; Pagano, J. Cognitive development in preschool children prenatally exposed to PCBs and MeHg. Neurotoxicol. Teratol. 2003, 25, 11 22.

(16)Stewart, P.W.; Lonky, E.; Reihman, J.; Pagano, J.; Gump, B.B.; Darvill, T. The relationship between prenatal PCB exposure and intelligence (IQ) in 9-year-old children. Environ. Health Perspect. 2008, 116, 1416-1422.

(17)Venier, M.; Dove, A.; Romanak, K.; Backus, S.; Hites, R. Flame retardants and legacy chemicals in the Great Lakes' water. Environ. Sci. Technol. 2014, 48, 9563-9572.

(18)Jeremiason, J.D.; Hornbuckle, K.C.; Eisenreich, S.J. PCBs in Lake Superior, 1978-1992: decreases in water concentrations reflect loss by volatilization. Environ. Sci. Technol. 1994, 28, 9]3-914.

(19)Jantunen, L.M.; Helm, P.A.; Ridal, J.J.; Bidleman, T.F. Air-water exchange of chiral and achiral organochlorine pesticides in the Great Lakes. Atmos. Environ. 2008, 42, 8533-8542.

(20)Morgan E.J. and Lohmann R. Detecting air-water and surface-deep water gradients of PCBs using polyethylene passive samplers. Environ. Sci. Technol. 2008, 42, 7248-7253.

(21)Huckins, J. N.; Petty, J.D.; Booij, K. Monitors of Organic Chemicals in the Environment Semipermeable Membrane Devices; Springer: New York, NY, 2006.

(22)Mayer, P.; Tolls, J.; Hermens, L.; Mackay, D. Equilibrium sampling devices. Environ. Sci. Technol. 2003, 37(9), 184A-191A.

(23)Ruge, Z.; Muir, D.; Helm, P.; Lohmann, R. Concentrations, trends, and air-water exchange of PAHs and PBDEs derived from passive samplers in Lake Superior in 2011. Environ. Sci. Technol. 2015, 49(23), 13777-13786.

(24)Zhang, L. and Lohmann, R. Cycling of PCBs and HCB in the surface ocean-lower atmosphere of the open Pacific. Environ. Sci. Technol. 2010, 44, 3832-3838.

(25)Zhang, L.; Bidleman, T.; Perry, M.J.; Lohmann, R. Fate of chiral and achiral organochlorne pesticides in the North Atlantic Bloom Experiment. Environ. Sci Technol. 2012, 46, 8106-8114.

(26)Adams, R.G; Lohmann, R.; Fernandez, L.A.; Macfarlane, J.K.; Gschwend, P.M. Polyethylene devices: Passive samplers for measuring dissolved hydrophobic organic compounds in aquatic environments. Environ. Sci. Technol. 2007, 41, 1317-1323.

(27)Lohmann, R. Critical review of low-density polyethylene's partitioning and diffusion coefficients for trace organic contaminants and implications for its use as a passive sampler. Environ. Sci. Technol. 2012, 46, 606-618.

(28)Baker, J.E. and Eisenreich S.J. Concentrations and fluxes of polycyclic aromatic hydrocarbons and polychlorinated biphenyls across the air-water interface of Lake Superior. Environ. Sci. Technol. 1990, 24, 342-352.

(29)Shen, L.; Wania, F.; Lei, Y.D.; Teixeira, C.; Muir, D.C.G.; Bidleman, T.F. Atmospheric distribution and long-range transport behavior of organochlorine pesticides in North America. Environ. Sci. Technol. 2005, 36, 409-420.

(30) Cooperating to implement the Great Lakes Water Quality Agreement: Technical Summary and Progress of the Integrated Atmospheric Deposition Network (IADN) 2002-2008; United StatesCanada IADN Scientific Steering Committee, October 2008.

(31)Bidleman, T.F.; Jantunen, L.M.M.; Wiberg, K.; Harner, T.; Brice, K.A.; Su, K.; Falconer, R.L.; Leone, A.D.; Aigner, E.J.; Parkhurst, W.J.; Soil as a source of atmospheric heptachlor epoxide. Environ. Sci. Technol. 1998, 32, 1546-1548.

(32)Bidleman, T. F., P. B. Kurt-Karakus, F. Wong, H. A. Alegria, L. M. Jantunen and H. Hung (2013). Is There Still "New" DDT in North America? An Investigation Using Proportions of DDT Compounds. 
Occurrence, Fate and Impact of Atmospheric Pollutants on Environmental and Human Health, American Chemical Society. 1149: 153-181.

(33)Health Effects Support Document for Aldrin/Dieldrin; United States Environmental Protection Agency, 2003; https://www.epa.gov/sites/production/files/201409/documents/support_cc1_aldrin-dieldrin_healtheffects.pdf.

(34)Aldrin and Dieldrin in drinking-water: Background document for development of WHO Guidelines for Drinking-water Quality; World Health Organization, 2003; WHO/SDE/WSH/03.03/73.

(35)EPA action to terminate endosulfan; United States Environmental Protection Agency, 2010; https://archive.epa.gov/pesticides/reregistration/web/html/endosulfan-cancl-fs.html.

(36)Hillery, B.R.; Basu, I.; Sweet, C.W.; Hites, R.A. Temporal and spatial trends in a long-term study of gas-phase PCB concentrations neat the Great Lakes. Environ. Sci. Technol. 1997, 31, 1811-1816.

(37)Honrath, R.E.; Sweet, C.I.; Plouff, C.J. Surface exchange and transport processes governing atmospheric PCB levels over Lake Superior. Environ. Sci. Technol. 1997, 31, 842-852.

(38)Sun, P.; Basu, I.; Blanchard, P.; Brice, K.A.; Hites, R.A. Temporal and spatial trends of atmospheric polychlorinated biphenyl concentrations near the Great Lakes. Environ. Sci. Technol. 2007, 41, 1131-1136.

(39)Shen, L.; Wania, F.; Lei, Y.D.; Teixeira, C.; Muir, D.C.G.; Bidleman, T.F. Hexachlorocyclohexanes in the North American Atmosphere. Environ. Sci. Technol. 2004, 38, 965-975.

(40)Perlinger, J.A.; Tobias, D.E.; Morrow, P.S.; Doskey, P.V. Evaluation of novel techniques for measurement of air-water exchange of persistent bioaccumulative toxicants in Lake Superior. Environ. Sci. Technol. 2005, 39, 8411-8419.

(41)Bennington, V.; McKinley, G.A.; Kimura, N.; Wu, C.H. General circulation of Lake Superior: Mean, variability, and trends from 1979 to 2006. J. Geophys. Res. 2010, 115, C12015.

(42)Dachs, J.; Lohmann, R.; Ockenden, W.A.O.; Méjanelle, L.; Eisenreich, S.J.; Jones, K.C. Oceanic biogeochemical controls on global dynamics of persistent organic pollutants. Environ. Sci. Technol. 2002, 36, 4229-4237.

(43)Jeremiason, J.D.; Eisenreich, S.J.; Baker, J.E.; Eadie, B.J. PCB decline in settling particles and benthic recycling of PCBs and PAHs in Lake Superior. Environ. Sci. Technol. 1998, 32, 3249-3256.

(44)Venier, M. and Hites, R.A. Regression model of partial pressures of PCBs, PAHs, and organochlorine pesticides in the Great Lakes' atmosphere. Environ. Sci. Technol. 2010, 44(2), 618-623.

(45)Khairy, M.; Muir, D. C.G.; Texeira, C.; Lohmann, R. Spatial Distribution, Air-Water Exchange and Source Apportionment of Polychlorinated Biphenyls in the Lower Great Lakes Basin. Environ. Sci. Technol. 2015, 49, 13787-13797, DOI: 10.1021/acs.est.5b00186.

(46)Joyce, A.S.; Portis, L.M.; Parks, A.N.; Burgess, R.M. Evaluating the Relationship between Equilibrium Passive Sampler Uptake and Aquatic Organism Bioaccumulation. Environ. Sci. Technol. 2016, 50, 11437-11451. 
Tables and Figures

Table 1: $\Sigma_{18} \mathrm{PCB}$ concentrations in gas-phase $\left(\mathrm{pg} \mathrm{m}^{-3}\right)$ and dissolved-phase $\left(\mathrm{pg} \mathrm{L}^{-1}\right)$ across Lake Superior by deployment period in 2011

\begin{tabular}{|c|c|c|c|c|c|c|}
\hline & \multicolumn{3}{|c|}{ Air $\left(p g \mathrm{~m}^{-3}\right)$} & \multicolumn{3}{|c|}{ Water $\left(\mathrm{pg} \mathrm{L}^{-1}\right)$} \\
\hline Site & April-June & June-August & August-October & April-June & June-August & August-October \\
\hline Sault Ste. Marie & 33 & 49 & 32 & 40 & 32 & 34 \\
\hline Pointe Aux Pins & & 2.1 & 1.1 & & 3.2 & 2.0 \\
\hline Ashland & 1.5 & 0.24 & 14 & 8.1 & 6.9 & 8.8 \\
\hline Thunder Bay/Welcome Isle & & 4.3 & 4.3 & & 2.3 & 2.0 \\
\hline Station 139 & & & & & 2.4 & 4.1 \\
\hline Marquette & 12 & 59 & 23 & 22 & 5.1 & $\mathrm{~N} / \mathrm{A}$ \\
\hline Ontonagon & & 0.6 & 24 & & 0.61 & 1.4 \\
\hline Duluth & 3.2 & 3.4 & 2.2 & & 7.4 & 2.3 \\
\hline Michipicoten Bay & & 0.80 & 0.62 & & 0.48 & 0.075 \\
\hline Sturgeon Bay & & 0.28 & 0.056 & & 0.20 & 0.87 \\
\hline Foster Island & & 0.69 & bd & & 0.090 & 0.19 \\
\hline Eagle Harbor & $b d$ & 0.063 & $\mathrm{bd}$ & & 0.015 & 0.20 \\
\hline Eastern Open Lake & & .83 & 0.030 & & 7.0 & 2.2 \\
\hline Central Open Lake & & 0.90 & bd & & 2.6 & 1.1 \\
\hline Western Open Lake & & 0.44 & $\mathrm{bd}$ & & 3.7 & 0.97 \\
\hline
\end{tabular}

$\Sigma_{18} \mathrm{PCB}=$ sum of CB-8, 18, 28, 44, 52, 66, 101, 105, 118, 128, 138, 153, 170, 180, 187, 195, 206, and 209

bd = below detection limit of GC/MS

$\mathrm{N} / \mathrm{A}=$ not available due to lost polyethylene samplers 
Table 2: June-October 2011 OCP concentrations in gas-phase $\left(\mathrm{pg} \mathrm{m}^{-3}\right)$ and dissolved-phase $\left(\mathrm{pg} \mathrm{L}^{-1}\right)$ averaged across deployment sites

\begin{tabular}{|c|c|c|c|c|c|c|c|c|c|c|c|c|}
\hline \multirow[b]{2}{*}{ OCP Analyte } & \multicolumn{6}{|c|}{ Air $\left(\mathrm{pg} \mathrm{m}^{-3}\right)$} & \multicolumn{6}{|c|}{ Water $\left(p g \mathrm{~L}^{-1}\right)^{\mathrm{a}}$} \\
\hline & Mean & Minimum & Maximum & Median & $\begin{array}{l}>\text { LOD } \\
\text { (of 28) }\end{array}$ & $\begin{array}{l}\text { No. Sites } \\
\text { (of 14) }\end{array}$ & Mean & Minimum & Maximum & Median & $\begin{array}{l}>\text { LOD } \\
\text { (of 26) }\end{array}$ & $\begin{array}{r}\text { No. Site } \\
\text { (of 13) }\end{array}$ \\
\hline$\alpha-\mathrm{HCH}$ & 4.3 & bd & 9.6 & 3.2 & 17 & 13 & 250 & 12 & 450 & 230 & 21 & 13 \\
\hline $\mathrm{HCB}$ & 88 & 42 & 130 & 91 & 27 & 14 & 17 & 5.4 & 37 & 17 & 26 & 13 \\
\hline Heptachlor epoxide & 0.67 & 0.30 & 1.1 & 0.61 & 27 & 14 & 3.8 & 1.1 & 5.5 & 3.5 & 26 & 13 \\
\hline Trans chlordane & 0.32 & 0.10 & 0.80 & 0.33 & 25 & 14 & 0.44 & 0.13 & 1.2 & 0.36 & 25 & 13 \\
\hline$\alpha$-Endosulfan & 1.7 & 0.33 & 2.7 & 2.0 & 26 & 14 & 0.63 & $b d$ & 2.1 & 0.33 & 7 & 7 \\
\hline Cis chlordane & 0.40 & 0.085 & 0.84 & 0.40 & 25 & 14 & 0.52 & 0.14 & 1.5 & 0.50 & 25 & 13 \\
\hline Trans nonachlor & 0.64 & 0.21 & 2.0 & 0.54 & 25 & 14 & 0.86 & 0.26 & 2.9 & 0.73 & 26 & 13 \\
\hline$p, p^{\prime}-D D E$ & 0.50 & 0.075 & 1.4 & 0.53 & 26 & 14 & 1.1 & 0.095 & 2.4 & 0.71 & 25 & 13 \\
\hline Dieldrin & 0.70 & $b d$ & 5.0 & $b d$ & 5 & 4 & 24 & bd & 73 & 30 & 12 & 7 \\
\hline$p, p^{\prime}-D D D+o, p^{\prime}-D D T$ & 0.14 & 0.018 & 0.44 & 0.11 & 23 & 14 & 0.84 & 0.095 & 8.2 & 0.21 & 21 & 13 \\
\hline$p, p^{\prime}-D D T$ & 0.054 & $b d$ & 0.33 & 0.012 & 9 & 8 & 0.15 & $b d$ & 0.68 & 0.090 & 14 & 10 \\
\hline
\end{tabular}

Calculations are based upon site averages from the second (June-August) and third (August-October) deployments

$\mathrm{bd}=$ below detection limit of GC/MS

${ }^{a}$ Excludes Marquette and Sturgeon Bay because not present during both June-August and August-October 2011

${ }^{\mathrm{b}}$ Analytes with medians below detection were excluded, except dieldrin 


\section{A}

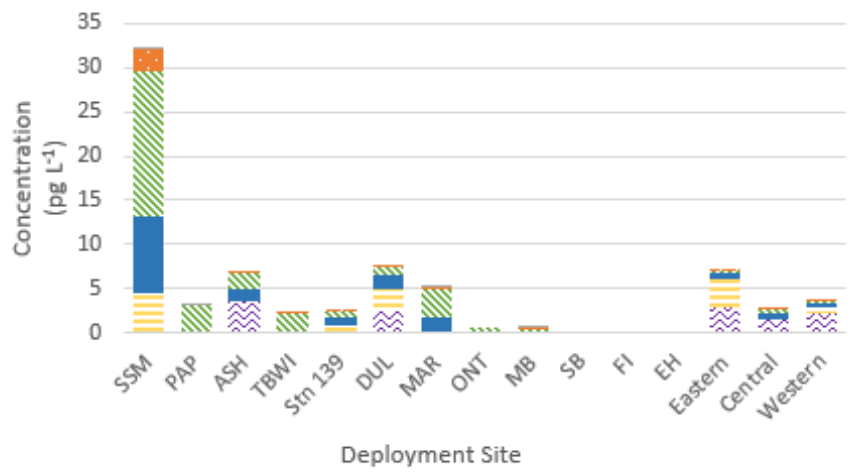

$\mathrm{C}$

PCB Air June-August

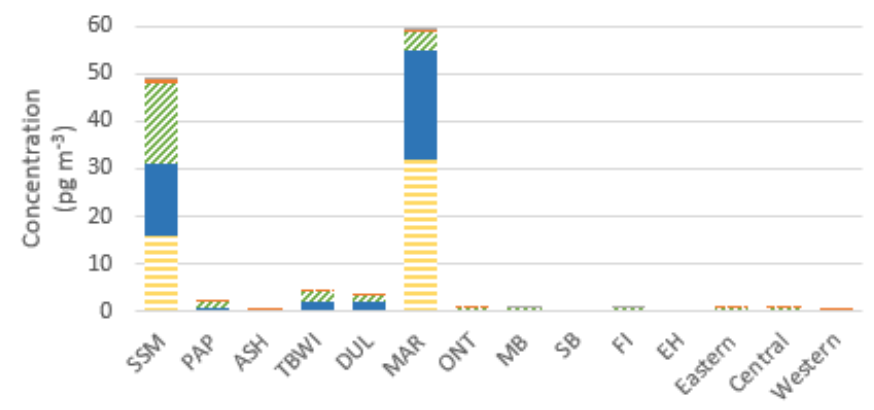

Deployment Site

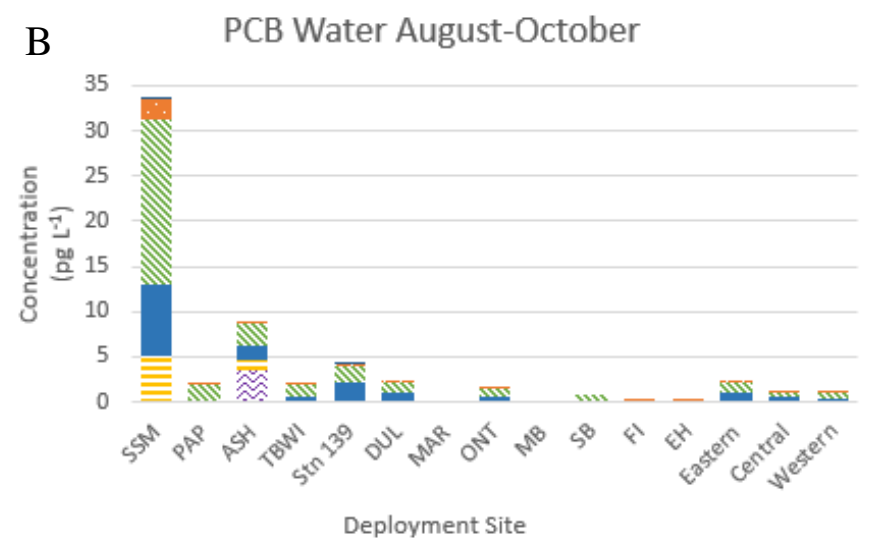

$\mathrm{D}$

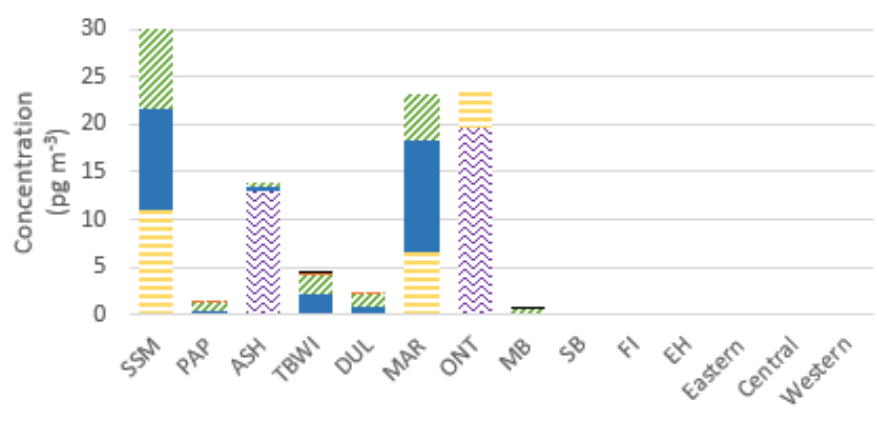

Deployment Site

Figure 1: Gaseous $\left(\mathrm{pg} \mathrm{m}^{-3}\right)$ and dissolved $\left(\mathrm{pg} \mathrm{L}^{-1}\right) \mathrm{PCB}$ concentrations at Lake Superior sampling sites grouped by degree of urban development. (A) Dissolved PCB concentrations averaged for June-August 2011. (B) Dissolved PCB concentrations averaged for August-October 2011. (C) Atmospheric PCB concentrations averaged for June-August 2011. (D) Atmospheric PCB concentrations averaged for August-October 2011. Legend: Pink = dichlorobiphenyl (CB8), Purple zigzag $=$ trichlorobiphenyls (CB18, 28), Yellow horizontal stripes $=$ tetrachlorobiphenyls $(\mathrm{CB} 44,52,66)$, Blue solid $=$ pentachlorobiphenyls $(\mathrm{CB} 101,105,118)$; Green diagonal stripes $=$ hexachlorobiphenyls $(\mathrm{CB} 128,138,153)$; Orange dotted $=$ heptachlorobiphenyls $(\mathrm{CB} 170,180,187) ;$ Grey $=$ octachlorobiphenyl (CB195); Red = nonachlorobiphenyl (CB206); and Black = decachlorobiphenyl (CB209). 
A

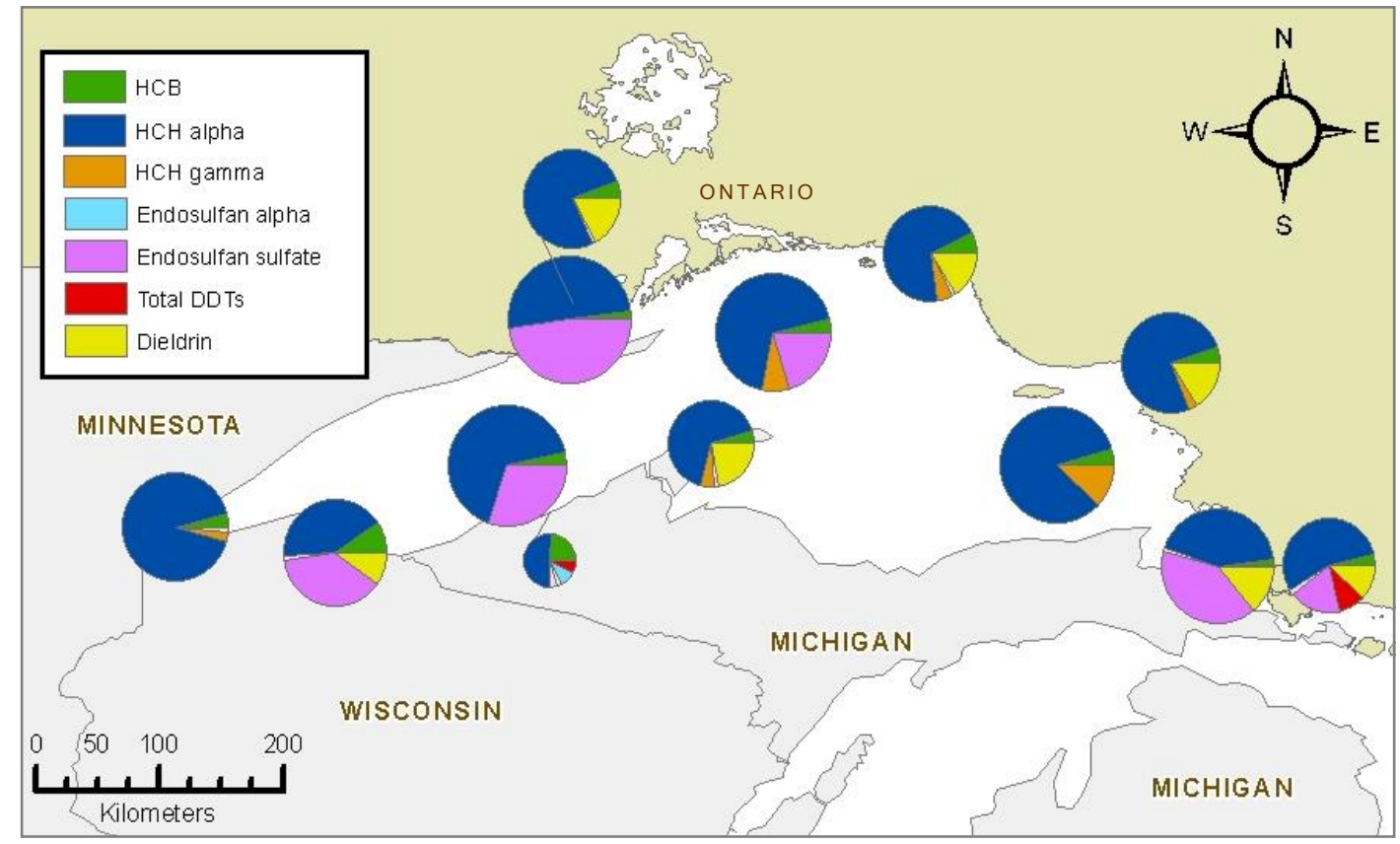

B

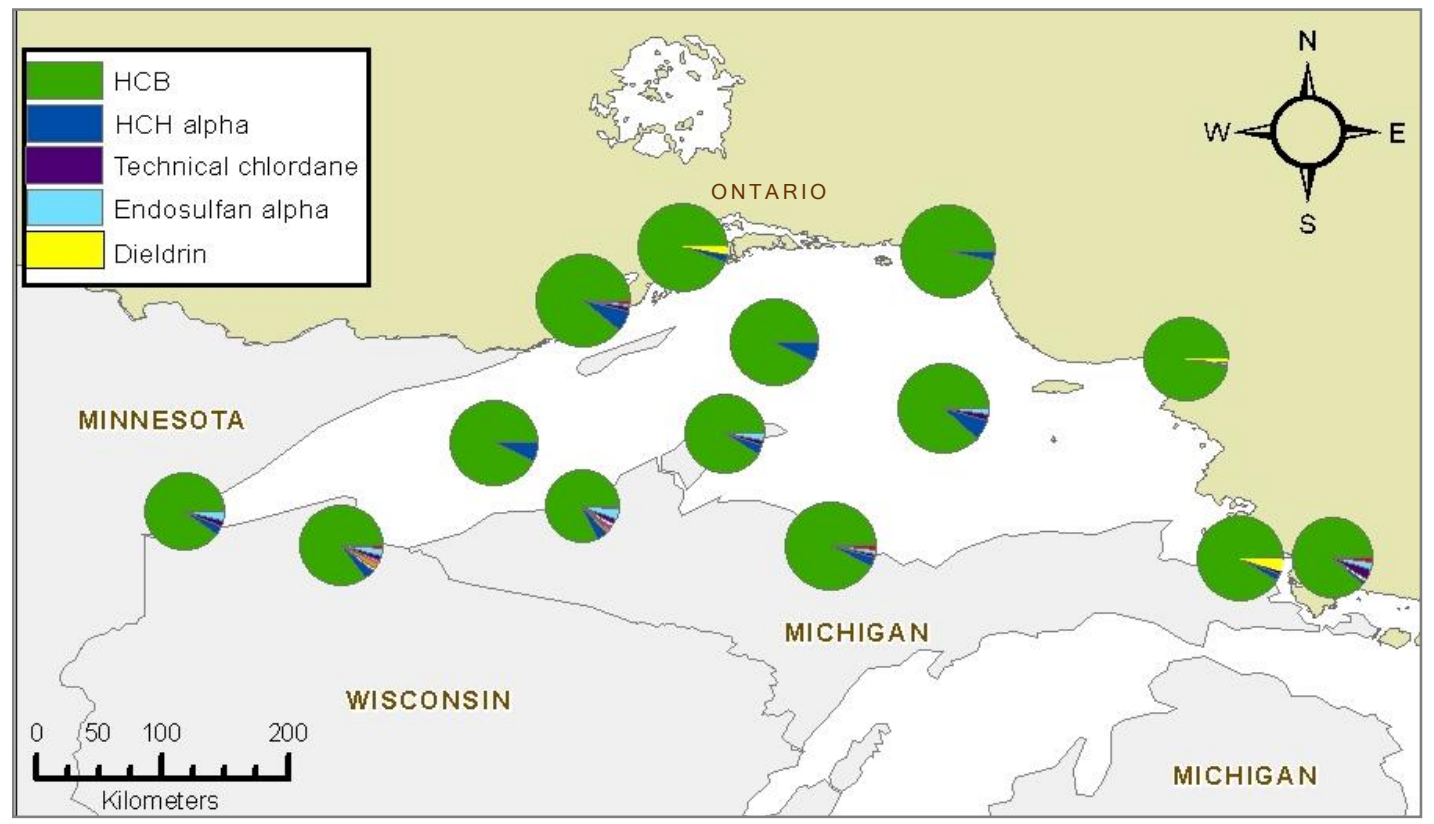

Figure 2: Relative average $\Sigma_{24} \mathrm{OCP}$ concentrations at each station for June-October 2011 indicated by circle size. (A) Surface water concentrations; average $\Sigma_{24} \mathrm{OCP}$ ranged from $23\left(\mathrm{pg} \mathrm{L}^{-1}\right)$ at Ontonagon to $770\left(\mathrm{pg} \mathrm{L}^{-1}\right)$ at Station 139, offshore from Thunder Bay/Welcome Isle. Marquette and Sturgeon Bay are not included because samplers were only recovered for June-August 2011.

(B) Air Concentrations; average $\Sigma_{24} \mathrm{OCP}$ ranged from $51\left(\mathrm{pg} \mathrm{m}^{-3}\right)$ at Ontonagon to $140\left(\mathrm{pg} \mathrm{m}^{-3}\right)$ at Thunder Bay/Welcome Isle and Foster Island. 


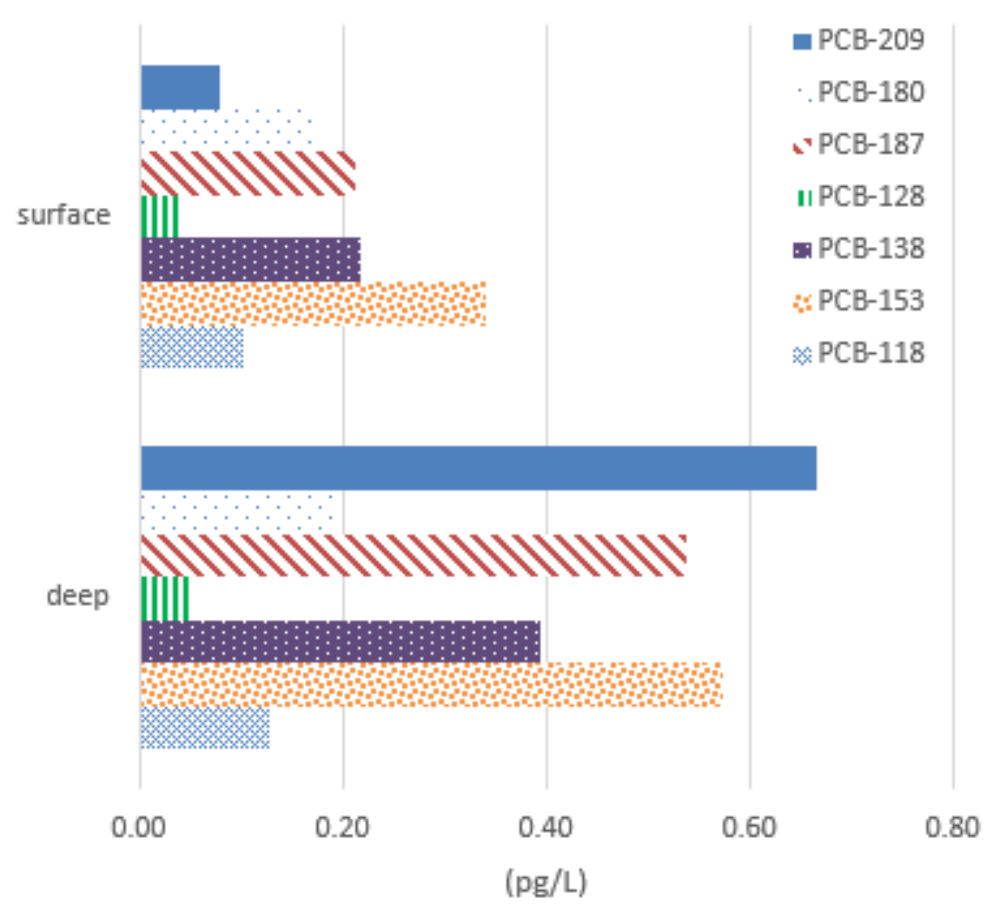

Figure 3: Dissolved water concentrations (pg/L) of seven PCB congeners collected using polyethylene passive samplers deployed at two depths (1m and 40m) in Lake Superior (48.860 N, 91.930 W) from May 15 - November 6, 2015. 